\title{
Saltern evaporation ponds as model systems for the study of primary production processes under hypersaline conditions
}

\author{
Aharon Oren \\ Department of Plant and Environmental Sciences, The Institute of Life Sciences, and the Moshe Shilo Minerva \\ Center for Marine Biogeochemistry, The Hebrew University of Jerusalem, Jerusalem, Israel
}

\begin{abstract}
Multi-pond solar salterns, which are used worldwide for salt production along tropical and subtropical coastal areas, present an environment with increasing salt concentrations, from seawater to $\mathrm{NaCl}$ saturation. Characteristic salt-adapted microbial communities are found along the salinity gradient. In ponds of intermediate salinity (100 to $250 \mathrm{~g} \mathrm{l}^{-1}$ ), most of the primary production occurs in benthic microbial mats dominated by different types of unicellular and filamentous Cyanobacteria (Aphanothece, Microcoleus, Phormidium and others), sometimes in association with diatoms. In crystallizer ponds, the unicellular green alga Dunaliella is the sole primary producer that lives in association with dense communities of heterotrophic halophilic Archaea that color the brines red. This basic pattern is common to all saltern systems, in spite of local variations in climate and nutrient availability. Photosynthetic activities of benthic cyanobacterial mats in the evaporation ponds and of endoevaporitic microbial communities within the gypsum crust that precipitates at intermediate salinities have been extensively studied in salterns at different locations, using oxygen microelectrodes and other techniques adapted to the study of benthic communities. These environments are generally highly productive, although most of the oxygen produced during daytime by the Cyanobacteria is recycled within the mats rather than exchanged with the overlying water and the atmosphere. Surprisingly few attempts have been made thus far to estimate the photosynthetic activity of Dunaliella, which is often present in numbers between $10^{3}$ and $10^{5}$ cells $\mathrm{ml}^{-1}$ in the heavily saltstressed environment of crystallizer ponds, so that the dynamics of the system is largely unknown.
\end{abstract}

KEY WORDS: Salterns $\cdot$ Cyanobacterial mats $\cdot$ Dunaliella $\cdot$ Primary production $\cdot$ Hypersaline

Resale or republication not permitted without written consent of the publisher

\section{INTRODUCTION}

Along tropical and subtropical coasts worldwide, we find saltern systems in which seawater is evaporated for the commercial production of common salt $(\mathrm{NaCl})$ and sometimes other salts as well. To obtain salt of high purity, such salterns are designed to consist of a series of shallow ponds in which the seawater is evaporated in stages, keeping the salinity of each pond within a narrow range. Calcium carbonate (calcite, aragonite) and calcium sulfate (gypsum) precipitate in the early stages of evaporation. Then sodium chloride (halite) precipitates in crystallizer ponds (total dissolved salt concentration $\sim 300$ to $\left.350 \mathrm{~g} \mathrm{l}^{-1}\right)^{\mathbf{1}}$. The remaining brines (the 'bitterns') that contain high concentrations of magnesium, potassium, chloride and sulfate are generally returned to the sea. Some coastal salt production facilities are very large, such as the Exportadora de Sal, Guerrero Negro, Baja California, Mexico which extends over $\sim 330 \mathrm{~km}^{2}$; others are much smaller, such as the well-studied salterns of the Israel

\footnotetext{
${ }^{1}$ In the literature on which this review is based, different units are used to express salt concentrations: $\mathrm{g} \mathrm{l}^{-1}, \mathrm{~g} \mathrm{~kg}^{-1}, \mathrm{~mol} \mathrm{l}^{-1}$ (for $\mathrm{NaCl}$ solutions), \%, \%, and ${ }^{\circ}$ Bé [degrees Baumé; the density in $\mathrm{g} \mathrm{ml}^{-1}$ being 145 / (145 - degrees Baumé)]. To enable easy comparison, total dissolved salt concentrations were converted here to $\mathrm{g}^{-1}$ wherever possible
} 
Salt Company near Eilat at the Red Sea coast of Israel, with a surface of only $2.3 \mathrm{~km}^{2}$.

Solar salterns contain rich and varied communities of phototrophic microorganisms along the saltern gradient, and the photosynthetic primary production by these communities largely determines the properties of the saltern system. The study of the communities of phototrophs that inhabit salterns is not only of purely scientific interest: the benthic cyanobacterial mats that develop in saltern ponds of intermediate salinity effectively seal the bottom of these ponds and prevent leakage of brine; on the other hand, unicellular Cyanobacteria in these mats and in the brine itself sometimes produce massive amounts of polysaccharide slime that unfavorably affects the salt production process (Davis 1993, Davis \& Giordano 1996). The red pigmentation of the dense microbial communities in crystallizer ponds is caused both by the $\beta$-carotene accumulated by the green alga Dunaliella salina which is the main or sole primary producer in these ponds, as well as by the carotenoid and retinal protein-based pigments of the heterotrophic community of prokaryotes that develop at the expense of photosynthetically fixed carbon derived from Dunaliella (Litchfield 1991). This red pigmentation increases light absorption by the brine and increases its temperature, thus enhancing the salt production process (Bonython 1966, Javor 1989, 2002). Even purely esthetic considerations have been used as incentive to study the highly diverse communities of phototrophic microorganisms in salterns (GundeCimerman et al. 2005, Oren 2005a). Thus, saltern pond systems have been studied extensively, and this review on phototrophs and photosynthetic activities is based on research performed in salterns in Australia, Bulgaria, France, Greece, India, Italy, Israel, Mexico, Puerto Rico, Slovenia, Spain, and others countries.

Characteristic salt-adapted microbial communities are found along the salinity gradient in salterns. This basic pattern is common to all saltern systems despite local variations in climate and nutrient availability. In ponds of intermediate salinity (100 to $250 \mathrm{~g} \mathrm{l}^{-1}$ ), most of the primary production occurs in benthic microbial mats dominated by different types of unicellular and filamentous Cyanobacteria (Aphanothece, Microcoleus, Oscillatoria, Phormidium and others) (Oren 2000), sometimes in association with diatoms. Below the cyanobacterial layers, a purple layer of anoxygenic phototrophic sulfur bacteria (Halochromatium, Ectothiorhodospira and related organisms) is often found. Especially beautiful are the layered communities of orange and dark-green Cyanobacteria and purple sulfur bacteria found embedded within the gypsum layers that precipitate at intermediate salinities (Caumette et al. 1994, Oren et al. 1995, Sørensen et al. 2004). Due to the elevated salinity, grazing is reduced, enabling the development of stratified benthic microbial mats that may often reach several centimeters in thickness.

In the crystallizer ponds where halite precipitates, benthic microbial mats are usually absent. The occurrence of a leathery layer of Microcoleus, locally called 'petola', on the bottom of the salt production ponds in the ancient, traditionally operated salterns of Sečovlje, Slovenia (Schneider 1995, Gunde-Cimerman et al. 2005) is an exception rather than the rule. The 'petola' develops during the earlier evaporation stages and apparently survives even after the salinity of the ponds has reached halite saturation. Photosynthetic activity under these conditions is probably negligible, but quantitative data are not available. Primary production is mostly limited to the planktonic unicellular green alga Dunaliella salina, which is often found in dense populations together with heterotrophic red Archaea (the flat square Haloquadratum walsbyi and other members of the Halobacteriaceae) and the red-orange Salinibacter (Bacteroidetes branch of the Bacteria), which all contain different carotenoid pigments as well as retinal proteins that may also contribute to the pink-red color of the brines.

This review primarily deals with the oxygenic photosynthetic microbial communities in salterns worldwide and the primary production they contribute to the saltern ecosystem. Our understanding of the dynamics of anoxygenic photosynthesis (e.g. the $\mathrm{CO}_{2}$ fixation activities of the purple sulfur bacteria that often occur in the benthic mats at lower salinity) and the contribution of chemoautotrophic bacteria to the overall carbon fixation in the ponds will also be discussed below, even though only limited data have been collected thus far.

Microbial processes in saltern ponds, including primary production by the halophilic algae and Cyanobacteria in the water and in the sediments, are largely comparable to processes occurring in natural salt lakes of similar salinity, from natural coastal lagoons to inland saline lakes. A study of the saltern ecosystem thus provides a convenient model for the understanding of the ecosystems in other seawaterderived and hypersaline environments. A discussion of primary production processes in such salt lakes and a comparison with phenomena observed in the artificial environment of the salterns may therefore be of interest. However, due to space limitation, this review will be restricted to data collected in coastal solar salterns, and no attempt is made to discuss the wealth of information on primary production in natural salt lakes of comparable salinity.

\section{METHODOLOGICAL CONSIDERATIONS}

The methods generally used to assess primary production in aquatic environments have been developed 
and optimized for use in freshwater and marine environments. Hypersaline environments pose special methodological problems, as many of the standard protocols used for chemical analysis in freshwater or seawater do not function properly at elevated salinities.

Part of the methods for the measurement of primary production are based on the monitoring of oxygen concentrations, which are evaluated by chemical methods (the Winkler titration) or by means of oxygen microelectrodes. Such microelectrodes have been extensively used in photosynthesis studies of hypersaline microbial mats in saltern evaporation ponds (Canfield \& Des Marais 1993, Caumette et al. 1994, Des Marais 1995). No special problems are reported to have been caused by the hypersaline nature of the medium that may necessitate special modifications in the construction or calibration of such electrodes. When used in studies of microbial activities in solid gypsum crusts, narrow holes may have to be drilled in the sediment to accommodate the electrodes, and the use of especially sturdy electrodes protected within a steel needle is recommended (Canfield et al. 2004, Sørensen et al. 2004). To stabilize the microbial community within the cyanobacterial mat to be used in oxygen microelectrode studies, it is possible to embed the mat in agar (Wieland \& Kühl 2006).

The Winkler titration can be applied even in the saltsaturated brines of crystallizer ponds. Incubation of 'light' and 'dark' bottles for $4 \mathrm{~h}$ at mid-day, followed by standard oxygen titration has also been successfully applied for the evaluation of photosynthetic activity in Spanish saltern ponds over the whole salt concentration range (Pedrós-Alió et al. 2000) and for the determination of oxygen concentration in water of $\sim 200 \mathrm{~g} \mathrm{l}^{-1}$ salt overlying a gypsum crust (Canfield et al. 2004). In some cases, the amount of sulfuric acid needed to dissolve the precipitate formed after the addition of the reagents has to be increased compared to the standard protocol (Javor 2002). Some authors (Javor 1983a, Sammy 1983) recommended the use of the azide modification of the Winkler procedure (Wright 1983).

At elevated salt concentrations, the solubility of oxygen and other gases in water is strongly reduced. This reduction sometimes results in conditions in crystallizer ponds being close to anaerobic, especially when the little oxygen that either enters from the atmosphere by diffusion or is produced by Dunaliella is taken up for respiration by the dense community of heterotrophic Archaea and Bacteria (Javor 1989). The values of 0.24 and $0.08 \mathrm{mg} \mathrm{l}^{-1}$ oxygen (7.5 and $2.5 \mu \mathrm{M}$, respectively) reported from Australian crystallizer pond waters with densities of 1.224 and $1.235 \mathrm{~g} \mathrm{ml}^{-1}$ (Sammy 1983) are probably the lowest values found in the literature. For comparison, air-saturated freshwater and standard seawater at $25^{\circ} \mathrm{C}$ contain 8.22 and $6.79 \mathrm{mg} \mathrm{l}^{-1}$ oxygen, which are equivalent to 257 and $212 \mu \mathrm{M}$ (Sherwood et al. 1991, 1992). A concentration of $1.87 \mathrm{mg} \mathrm{l}^{-1}(58 \mu \mathrm{M})$ oxygen was reported in the crystallizer brines of a Bulgarian salt works (Pavlova et al. 1998). Canfield et al. (2004) found saturation concentrations of 82 and $69 \mu \mathrm{M}$ oxygen at $20^{\circ} \mathrm{C}$ in brines of 230 and $200 \mathrm{~g} \mathrm{l}^{-1}$ total dissolved salts overlying a gypsum crust in the salterns of Eilat, Israel.

When using primary production assays that involve measurement of the incorporation of ${ }^{14} \mathrm{C}$-labeled bicarbonate, considerable errors may be introduced since the carbonate system behaves differently in salterns than in seawater (Javor 2002). Estimates of total inorganic carbon based on standard alkalinity titrations need to be corrected using a salinity-dependent factor (Burke \& Atkinson 1988). This approach has been used by Joint et al. (2002) in their study of primary production along the salt gradient in a Spanish saltern. An alternative is to determine the total inorganic carbon in the brines using a $\mathrm{CO}_{2}$ analyzer (Wieland et al. 2005).

Specific problems may also arise in ${ }^{14} \mathrm{C}$-labeling studies due to the special nature of some of the photosynthetic species responsible for the $\mathrm{CO}_{2}$ fixation in salterns. The cells of Dunaliella, which lack a rigid cell wall, are very fragile and easily broken during filtration. Moreover, such cells transform a significant fraction of the carbon fixed into glycerol, which is accumulated inside the cell up to molar concentrations to provide osmotic balance of the cytoplasm with the salty brines. Glycerol may therefore be one of the key compounds used by the heterotrophic communities in such ponds (Oren 1993, 1995). A study of the marine species $D$. tertiolecta showed that up to half of the fixed carbon could be lost during filtration on polycarbonate filters, especially when the filters were left dry between rinses. The pressure difference applied to the vacuum filtration system was also found to influence the amount of label lost (Goldman \& Dennett 1985). It may be assumed that the problem could be even more severe for $D$. salina in crystallizer brines, as they contain much higher glycerol concentrations than marine species, and a greater differential pressure is needed to filter the highly viscous saltern brines through small-pore membrane filters. The question 'To what extent are the very low primary production values reported by Joint et al. (2002) for the crystallizer ponds of a Spanish saltern underestimated relative to the true values as a result of massive cell lysis during vacuum filtration on $0.2 \mu \mathrm{m}$ pore size polycarbonate filters?' should therefore be asked.

Flow cytometry has thus far been seldom used to estimate the numbers and biomass of planktonic phototrophs in saltern ponds, but a recent study shows that the technique can be employed in hypersaline systems (Estrada et al. 2004). 


\section{CYANOBACTERIA-DOMINATED MICROBIAL MATS IN THE EARLY CONCENTRATION PONDS}

In the first sets of ponds in saltern operations, seawater is concentrated from $\sim 35$ to $100-120 \mathrm{~g} \mathrm{l}^{-1}$ total dissolved salts. In the process, small amounts of $\mathrm{CaCO}_{3}$ precipitate to the bottom as calcite or aragonite, but the bottom layers are generally soft. Dense microbial mats consisting of Cyanobacteria, anoxygenic phototrophic bacteria, a variety of heterotrophic prokaryotes, diatoms, Protozoa, and other microorganisms often develop on the bottom of such ponds. Slimy polysaccharides excreted by the biota cause the formation of a cohesive microbial mass that may sometimes reach several centimeters in depth.

The filamentous cyanobacterium Microcoleus chthonoplastes is often one of the most prominent members of the phototrophic community in such benthic mats. In the Guerrero Negro salterns of Baja California, it dominated the ecosystem at salt concentrations of up to $110 \mathrm{~g} \mathrm{l}^{-1}$ (Des Marais 1995, Nübel et al. 2000, Decker et al. 2005). We find such mats of Microcoleus, often accompanied by Lyngbya species, also in salterns in the south of France (Fourçans et al. 2004), Spain (Thomas 1984), Puerto Rico (Casillas-Martinez et al. 2005) and elsewhere. At somewhat higher salt concentrations $\left(140 \mathrm{~g} \mathrm{l}^{-1}\right)$, the unicellular Euhalothece (Aphanothece) and the filamentous Halospirulina became dominant in the Guerrero Negro evaporation ponds (Nübel et al. 2000). Other Cyanobacteria reported to abound in such benthic mats include Oscillatoria sp., Halomicronema, Microcystis, Chroococcus, Gloeocapsa, Synechocystis, Leptolyngbya, Phormidium, Pleurocapsa, and Calothrix (Des Marais 1995, Oren 2000, Fourçans et al. 2004). There is often considerable confusion about the proper identification of the organisms present, and some of these Cyanobacteria are known under more than one name (Oren 2000). Diatoms such as Nitzschia are often present (Wieland et al. 2005), but the Cyanobacteria are quantitatively the main photosynthetic component of the system. Anoxygenic phototrophs (different types of Chromatiaceae and Ectothiorhodospiraceae, as well as green non-sulfur bacteria of the Chloroflexi group) and filamentous chemolithotrophs (Beggiatoa and relatives) abound as well in such mats.

Most attempts to estimate primary production in such benthic photosynthetic mat systems have employed oxygen microelectrodes, following changes in the ambient oxygen concentration at different depths during light-dark shifts. Such measurements yield information about both gross primary production at any defined depth and the community respiration and other oxygen sinks. Little information is obtained about the fluxes of oxygen from or into the system at any time, and the different techniques and calculation methods used by different investigators make direct comparison of data often difficult. While attempting to also estimate the net evolution and/or uptake of oxygen by such mats, some studies have measured changes in oxygen concentration in the overlying water in cores upon illumination (Wieland et al. 2005), or used flow chambers to assess changes in oxygen concentration mediated by the microbial mat communities (Wieland \& Kühl 2006). Table 1 summarizes the photosynthetic activities of such benthic photosynthetic mats as studied in saltern ponds at different locations. Because of the diversity of techniques and approaches used in the different studies, direct comparison of the primary production values quoted by the authors is not always possible.

Exposure of a Microcoleus-dominated mat from a $100 \mathrm{~g} \mathrm{l}^{-1}$ salinity pond of the Salin de Giraud (France) saltern to changes in salt concentration resulted in little change in net photosynthesis activity when salinity was decreased to $40 \mathrm{~g} \mathrm{l}^{-1}$, but rates decreased at elevated salt concentrations of up to $160 \mathrm{~g} \mathrm{l}^{-1}$ at all levels of irradiance (Wieland \& Kühl 2006). This behavior is consistent with that of Microcoleus in laboratory culture (Oren 2000). Dark oxygen consumption rates and gross photosynthetic rates at light saturation were also relatively constant over a broad salinity range $\left(60-100 \mathrm{~g} \mathrm{l}^{-1}\right)$. Within the range of natural variation in the mat, temperature was more important than salinity in regulating photosynthesis and oxygen consumption (Wieland \& Kühl 2006).

The in-depth studies of Canfield \& Des Marais in the Guerrero Negro evaporation ponds (salinity 65 to $125 \mathrm{~g}$ $\mathrm{l}^{-1}$ ) provide interesting information on the primary productivity of such mats. Monitoring of oxygen profiles and measurements of kinetic parameters during day-night cycles enabled the establishment of a detailed model. During daytime, most of the oxygen formed in the mat is recycled locally by respiration of organic carbon and by oxidation of sulfide that diffuses from the deeper layers. At night, oxidation of sulfide near the mat-water interface is the main oxygen-consuming process. Dissimilatory sulfate reduction is the principal source of dissolved inorganic carbon at night. The oxygen and dissolved inorganic carbon fluxes were found to balance over a $24 \mathrm{~h}$ cycle. However, a careful comparison of the oxygen and dissolved inorganic carbon fluxes across the mat-water interface revealed that during the day, there is more inorganic carbon diffusing into the mat than oxygen diffusing out; at night, more inorganic carbon diffuses out of the mat than oxygen that diffuses in. Thus, relatively oxidized carbon compounds appear to be incorporated into the mat during the day, and these oxidized compounds are respired by the mat at night. The chemical 


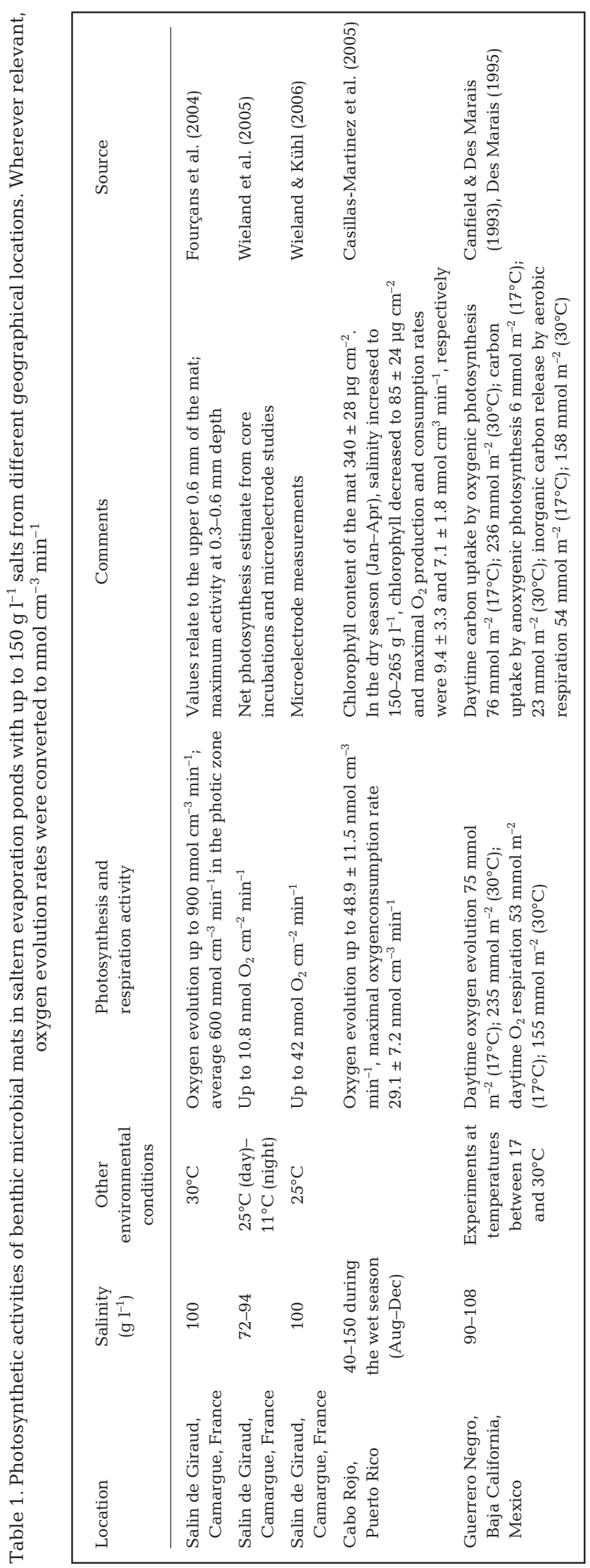

nature of this carbon is still unknown (Canfield \& Des Marais 1993, Des Marais 1995). An alternative explanation for the unexpected carbon to oxygen ratios may be the underestimation of net photosynthesis by the measured oxygen flux due to consumption of oxygen by the oxidation of metal sulfides accumulated during the dark period (Wieland et al. 2005).

\section{PHOTOSYNTHETIC PROCESSES IN BENTHIC GYPSUM CRUSTS}

When the evaporation of seawater has proceeded so that salinity is 3 to $4 \times$ the original salinity, the solubility of calcium sulfate is exceeded, and gypsum $\left(\mathrm{CaSO}_{4} \cdot 2 \mathrm{H}_{2} \mathrm{O}\right)$ precipitates at the bottom of the ponds. In some saltern systems, gypsum accumulates in ponds with a salinity of 150 to $250 \mathrm{~g} \mathrm{l}^{-1}$ in a crust of many centimeters thickness. Layered communities of phototrophic microorganisms are characteristically found in the gypsum: an upper layer of carotenoid-rich orange-colored Cyanobacteria of the Euhalothece-Aphanothece group (Garcia-Pichel et al. 1998), below which a dark-green layer of Phormidium-type filamentous Cyanobacteria occurs. Underneath, a purple layer of Halochromatium and Ectothiorhodospira performs anoxy- genic photosynthesis, with sulfide derived from sulfate reduction in the anaerobic layers below as electron donor. The gypsum crystals are often arranged such that light penetrates deep into the crust, allowing for the possibility of active photosynthesis down to depths of similar centimeters. Such layered phototrophic communities have been described from salterns in the south of France (Cornée 1982, Caumette et al. 1994), in Spain (Ortí Cabo et al. 1984, Thomas 1984) and Israel (Oren et al. 1995, Oren 1997, Canfield et al. 2004, Sørensen et al. 2004, 2005, Ionescu et al. 2007, Oren et al. 2009).

Oxygen microelectrodes have been used to estimate primary production and other photosynthesis-related parameters in the gypsum crusts of the Salin de Giraud, France (Caumette et al. 1994) and the Israel Salt Company in Eilat (Canfield et al. 2004). The results of these studies are summarized in Table 2. Overall, photosynthetic rates in the Eilat gypsum crust were much lower than those typically found in organic-rich microbial mats at lower salinities. However, on a per cell-volume basis, the rates were comparable. Microelectrode measurements also showed that the green layer, which receives $\sim 0.1 \%$ of the light intensity at the surface of the crust (Oren et al. 1995), was adapted to function at extremely low light intensities, and was light-saturated during much of the day (Canfield et al. 2004). A large percentage of the oxygen produced during the day accumulated inside the crust and was internally recycled, and only a relatively 


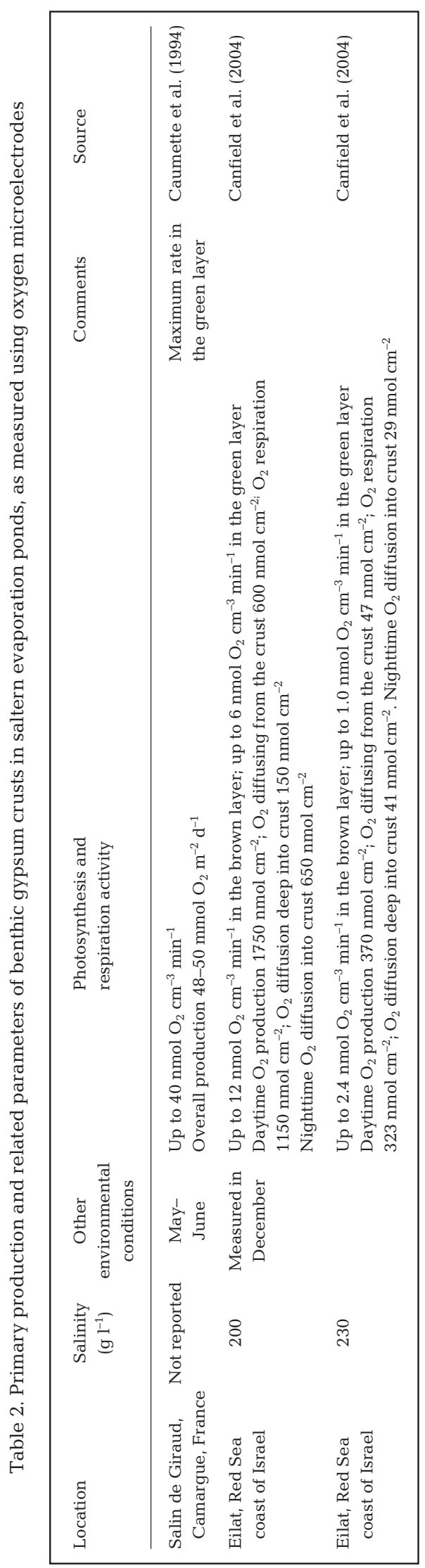

small percentage of the oxygen produced (16 to $34 \%$ ) escaped. For comparison, $30 \%$ of the oxygen produced during the first half of the light cycle accumulated in the Eilat crust, while $<1 \%$ accumulated in the Guerrero Negro crust (Canfield \& Des Marais 1993).

A prominent feature of the microbial mats within the gypsum crusts, as well as in the evaporation ponds of lower salinity, is the often copious amounts of polysaccharide slime associated with the growth of the unicellular Euhalothece-Aphanothece Cyanobacteria. These organisms also spread into the overlying water in some saltern systems. Massive slime formation can negatively affect the salt production process (De Medeiros Rocha \& Camara 1993, Rahaman et al. 1993, Roux 1996). Lack of inorganic nutrients (nitrogen, phosphorus) may induce the cells to dispose of the photosynthetically fixed carbon in the form of these extracellular polysaccharides (Roux 1996).

The ambient salinity is one of the key factors determining the photosynthetic rates of the cyanobacterial community in the hypersaline gypsum crusts. Reduction of the salinity of such a crust in Eilat from 230 to $200 \mathrm{~g} \mathrm{l}^{-1}$ increased oxygen production, as measured by a microelectrode, from $<2$ to $8-9 \mu \mathrm{M} \mathrm{min}^{-1}$ (Canfield et al. 2004). Such results are also consistent with pure culture studies showing that species of Aphanothece/ Euhalothece that dominate the community have their salinity optimum far below that found in the gypsum crusts and the overlying brines (Garcia-Pichel et al. 1998, Oren 2000). However, ${ }^{14} \mathrm{C}$-bicarbonate uptake in slurries of gypsum crust (215 $\mathrm{g} \mathrm{l}^{-1}$ salt in the overlying brine) showed optimal photosynthetic activity between 180 and $240 \mathrm{~g} \mathrm{l}^{-1}$ salt in the upper brown-orange layer and between 80 and $230 \mathrm{~g} \mathrm{l}^{-1}$ salt in the green layer below (Sørensen et al. 2004).

The use of sulfide microelectrodes enabled the estimation of the photosynthetic rates of the purple sulfur bacteria community in the gypsum crust in the Salin de Giraud salterns. Monitoring of the changes in sulfide concentration in the red-purple layer of anoxygenic phototrophs following light-dark shifts yielded a sulfide oxidation rate of $12.7 \mu \mathrm{mol} \mathrm{cm} \mathrm{min}^{-1}$ in the light, corresponding to $180-330 \mathrm{mmol}$ sulfide $\mathrm{m}^{-2} \mathrm{~d}^{-1}$ oxidized photosynthetically (based on 8 to $10 \mathrm{~h}$ of daylight and a $3 \mathrm{~mm}$ thick zone of phototrophic sulfide oxidation). At a stoichiometry of $2 \mathrm{~mol} \mathrm{CO}_{2}$ fixed autotrophically $\mathrm{mol}^{-1}$ of sulfide oxidized to sulfate, this would be equal to 360-660 mmol $\mathrm{CO}_{2} \mathrm{~m}^{-2} \mathrm{~d}^{-1}$. It was estimated that between 65 and $95 \%$ of the sulfide produced in the lower layers was oxidized phototrophically in the crust (Caumette et al. 1994). The remainder may be oxidized chemically as well as biologically by chemoautotrophic sulfur bacteria. Measurements of ${ }^{14} \mathrm{C}$-labeled bicarbonate uptake by slurries prepared from the purple layer of the Eilat gypsum crust in the light and in the presence 
of sulfide showed optimal activity at 100 to $120 \mathrm{~g} \mathrm{l}^{-1}$ salt, which is far below concentrations in the crust in which the community had developed $\left(215 \mathrm{~g} \mathrm{l}^{-1}\right)$ (Sørensen et al. 2004). No further estimates of the contribution of chemoautotrophic sulfur bacteria to the $\mathrm{CO}_{2}$ fixation process in the benthic microbial communities in saltern ponds could be found in the literature.

\section{PLANKTONIC PRIMARY PRODUCERS AND PRIMARY PRODUCTION IN EVAPORATION PONDS}

In contrast to the extensive studies of primary production in benthic cyanobacterial mats in saltern evaporation ponds of low and intermediate salinity, surprisingly little research has yet been devoted to primary production processes in the brines overlying these sediments. Joint et al. (2002) measured planktonic chlorophyll and 'potential' primary production (by ${ }^{14} \mathrm{C}$-bicarbonate uptake in $3 \mathrm{~h}$ laboratory incubations at a light intensity of $275 \mu \mathrm{mol}$ quanta $\mathrm{m}^{-2} \mathrm{~s}^{-1}$ ) along the salinity gradient in the salterns of Alicante, Spain in May 1999. Chl a concentrations in the first ponds fed with Mediterranean water were $\sim 4 \mu \mathrm{g} \mathrm{l^{-1 }}$, increasing to $\sim 8 \mu \mathrm{g} \mathrm{l}^{-1}$ at 54-102 $\mathrm{g} \mathrm{l}^{-1}$ salinity, then decreasing to low values with increasing salinity, to increase again in the crystallizer ponds at a salinity above $320 \mathrm{~g} \mathrm{l}^{-1}$. The highest potential photosynthetic rate $\left(38.6 \mu \mathrm{g} \mathrm{Cl}^{-1} \mathrm{~h}^{-1}\right.$; $4.9 \mu \mathrm{g} \mathrm{C} \mu \mathrm{g} \mathrm{chl} \mathrm{a}^{-1} \mathrm{~h}^{-1}$ ) was measured at $80 \mathrm{~g} \mathrm{l}^{-1}$ salinity. High activities were also measured at 54 and $110 \mathrm{~g}$ $\mathrm{l}^{-1}$ salinity. In the first set of ponds $\left(40 \mathrm{~g} \mathrm{l}^{-1}\right.$ salt), activity was much lower $\left(7.8 \mu \mathrm{g} \mathrm{C}^{-1} \mathrm{~h}^{-1}\right)$. Dark carbon fixation was high throughout the salt gradient: in most ponds the light:dark ratio of ${ }^{14} \mathrm{C}$ fixation was $\sim 1.3$.

Incubation experiments of the above-mentioned samples were conducted for $24 \mathrm{~h}$, with simultaneous measurement of nitrate and ammonium uptake. In these experiments, a dark period was included to estimate net rather than gross production. At salt concentrations below $110 \mathrm{~g} \mathrm{l}^{-1}$, the C:N uptake ratio was higher than the classic Redfield ratio of $16: 1$, but unexpectedly decreased to $\sim 1.0$ at $220 \mathrm{~g} \mathrm{l}^{-1}$ salinity and an even lower value (0.8) was estimated in a crystallizer pond at $370 \mathrm{~g} \mathrm{l}^{-1}$ salinity. If the analytical methods and calculations were indeed reliable, no obvious explanation can be brought forward for these observations.

\section{PLANKTONIC PRIMARY PRODUCTION IN SALTERN CRYSTALLIZER PONDS}

Michel Felix Dunal first saw the unicellular flagellate red-colored algae we know today as Dunaliella salina in saltern brines on the Mediterranean coast of France in 1838, and named the organism 'Haematococcus sali- nus' (Oren 2005b). This organism is the main phototrophic organism encountered in saltern crystallizer ponds all over the world, and is usually the only primary producer there. Large amounts of $\beta$-carotene are accumulated as globules between the thylakoids of the single chloroplast, and the pigment protects the cells from damage by high light intensities. Dunaliella is one of the causes of the pink-red coloration of saltern crystallizer brines; however, although $\beta$-carotene may be present in the biomass in amounts exceeding those of the bacterioruberin pigments of the halophilic Archaea, the algal pigment contributes only a minor part to the overall color of the brines because of its dense packaging (Oren et al. 1992, Oren \& Dubinsky 1994).

Dunaliella salina has a broad salinity range, grows optimally at salt concentrations of 120 to $140 \mathrm{~g} \mathrm{l}^{-1}$ in the laboratory, but also tolerates $270 \mathrm{~g} \mathrm{l}^{-1}$ and above. At the highest salinities $\left(>200 \mathrm{~g}^{-1}\right)$, D. salina grows faster than smaller Dunaliella species such as D. parva and D. viridis (Gibor 1956, Margheri et al. 1987, Oren 2005b). At lower salt concentrations, D. salina is generally outcompeted by other phototrophs, but the alga was found in relatively low numbers (5 to $22 \%$ of the total cell counts) in the evaporation ponds of the Megalon Embolon solar salt works in northern Greece at 65 to $144 \mathrm{~g} \mathrm{l}^{-1}$ salt (Dolapsakis et al. 2005).

The population density of Dunaliella in crystallizer ponds varies greatly according to geographic location, nutrient status, and management of the salterns. Despite the fact that ecophysiological studies on Dunaliella were already started in the 1920s in attempts to understand its dynamics in salterns (Labbé 1921, Oren 2005b), we still know surprisingly little about its behavior in salt-saturated brines. In the Eilat salterns, the numbers of $D$. salina in the crystallizer ponds were found to vary between 160 and 2960 cells ml ${ }^{-1}$ (Oren et al. 1992, Oren 1993, Oren \& Dubinsky 1994, Oren 1995). Far larger numbers were observed in the crystallizer ponds of salterns on the Mediterranean coast of Spain: up to 100000 cells $\mathrm{ml}^{-1}$ at $300 \mathrm{~g} \mathrm{l}^{-1}$ salt, decreasing to $\sim 5000$ cells $\mathrm{ml}^{-1}$ at $380 \mathrm{~g} \mathrm{l}^{-1}$ salt (RodriguezValera et al. 1985). Patchy growth may sometimes lead to considerable spatial variation: on the 4 sides of a single pond of $370 \mathrm{~g} \mathrm{l}^{-1}$ salt, cell numbers varied between 5090 and $10500 \mathrm{ml}^{-1}$, with chl a concentrations between 23.6 and $45.7 \mu^{-1} \mathrm{l}^{-1}$ (Joint et al. 2002).

Surprisingly few attempts have been made to assess the in situ photosynthetic activity of Dunaliella in saltern crystallizer ponds. In the salterns of Alicante, Spain, oxygen evolution/consumption was measured in light and dark bottles incubated for $4 \mathrm{~h}$ around noon. In ponds of intermediate (200 to $250 \mathrm{~g} \mathrm{l}^{-1}$ ) salinity, with $3.6 \mathrm{Mg} \mathrm{l}^{-1} \mathrm{chl} \mathrm{a}_{\text {, and }} 74$ to $96 \%$ of the biovolume being Dunaliella and 4 to $9 \%$ being Cyanobacteria, gross production was estimated at 0.07 to $1.27 \mathrm{mg} \mathrm{C}^{-1} \mathrm{~d}^{-1}$. Sur- 
prisingly, primary production in the crystallizer ponds (>300 $\mathrm{g} \mathrm{l}^{-1}$ salt) was below the detection limit, despite the presence of $3.5 \mu \mathrm{g} \mathrm{l}^{-1} \mathrm{chl} a$, which was attributed entirely to Dunaliella (Pedrós-Alió et al. 2000). Also in a later study performed in the same ponds, this time measuring photoassimilation of ${ }^{14} \mathrm{C}$-labeled bicarbonate during $3 \mathrm{~h}$ periods, very low rates of carbon fixation were found, despite the high chlorophyll concentrations present. Reported rates were as low as 27.5 to $56 \mu \mathrm{g} \mathrm{Cl}^{-1} \mathrm{~d}^{-1}$ in the light and 20.8 to $23.8 \mu \mathrm{g} \mathrm{Cl}^{-1} \mathrm{~d}^{-1}$ in the dark, or $0.1 \mu \mathrm{g} \mathrm{C}(\mu \mathrm{g} \mathrm{chl} a)^{-1} \mathrm{~h}^{-1}$ in brine of $370 \mathrm{~g} \mathrm{l}^{-1}$ salt (Joint et al. 2002). As discussed above, the filtration procedure used to separate the cells from the liquid may have caused considerable cell breakage, leading to a significant underestimation of the true rates. Monitoring diel changes in oxygen concentrations in mesocosms filled with brine from the crystallizer ponds in Eilat, Israel (1300 to 2100 Dunaliella cells $\mathrm{ml}^{-1}$ ) gave net primary production rates of $\sim 0.8$ to $1.5 \mu \mathrm{mol} \mathrm{O} \mathrm{O}^{-1} \mathrm{~h}^{-1}$ (Elevi Bardavid et al. 2008). These rates of 120 to $220 \mu \mathrm{g}$ $\mathrm{C}^{-1} \mathrm{~d}^{-1}$, based on a $12 \mathrm{~h}$ daylight time, are significantly higher than those quoted above from the study of Joint et al. (2002) in the Spanish saltern ponds populated by far denser Dunaliella communities. Collectively, these results show that the crystallizer brines are far from being an optimal environment for the alga, both because of supraoptimal salinities and high light intensities, but possibly also because of limitation of iron and other essential nutrients (see next section).

\section{AVAILABILITY OF INORGANIC NUTRIENTS TO THE PHOTOSYNTHETIC MICROBIAL COMMUNITY IN THE SALTERNS}

Salterns worldwide vary greatly in the concentrations of inorganic nutrients of the brines. These variations depend on geographical location, season, management practices, and many other factors. The ambient nutrient concentrations within a single pond can also vary considerably even within a few days, as shown in the study of Joint et al. (2002) in the salterns of Santa Pola, Alicante, Spain. Nutrients (nitrogen and/or phosphorus) are sometimes added as fertilizers to enhance the development of benthic microbial mats or planktonic communities of light-absorbing microorganisms (Davis 1993). Table 3 summarizes data on ammonium, nitrate, and phosphate concentrations in saltern ponds of different salt concentrations at diverse locations.

When comparing the values presented in the table, it should be noted that different analytical methods have been used in the studies cited, and that the data may therefore not always be comparable. Standard methods for the analysis of seawater, including automated assays using autoanalyzers, can generally be used after dilution of the samples with distilled water to seawater salinity (Pedrós-Alió et al. 2000). Such dilution necessarily reduces the sensitivity and the detection limit of the procedure, but this only rarely causes problems as the concentrations to be measured are often high. The phenol hypochlorite method for ammonia determination (Solórzano 1969) can be used in hypersaline solutions of up to $125 \mathrm{~g} \mathrm{l}^{-1}$ salt (Javor 2002). To properly calibrate the analytical methods, it is good practice to spike the brine samples with known concentrations of the nutrient to be measured and to check recovery. Unfortunately, this is probably seldom done, except for the study of Coleman \& White (1993) in the Cheetham salterns in Queensland, Australia.

In most saltern systems, nutrient concentrations increase with increasing salinity. This may be due both to the evaporative concentration of the water and to bacterial activity. Water birds are often found in great numbers near the evaporation ponds, and their droppings can also add to the nutrient load of the salterns. The benthic microbial mats can act as nutrient scavengers as well as nutrient sources. Thus, the sharp increase in ammonium concentration in the Cabo Rojo (Puerto Rico) saltern evaporation ponds during the wet season was tentatively explained by the microbial degradation of nitrogen-containing osmolytes (glycine betaine, ectoine, etc.) accumulated by the microbial community during the dry season (Casillas-Martinez et al. 2005). Phosphate concentrations were found to increase sharply with depth in the interstitial waters of the benthic microbial mat in an Australian saltern, from $<0.3 \mu \mathrm{M}$ in the upper $10 \mathrm{~mm}$ to $15 \mu \mathrm{M}$ at a depth of $82 \mathrm{~mm}$, due to the anaerobic breakdown of organic matter (Coleman \& White 1993). To what extent primary production in benthic cyanobacterial mats in the salterns may be limited by a lack of inorganic nutrients has never been ascertained. The effect of nutrient addition on gross photosynthesis and respiration has been investigated in similar mats in Lake Chiprana, an inland salt lake in Spain. The addition of ammonia or phosphate did not change net photosynthesis, but phosphate $(100 \mu \mathrm{M})$ stimulated both gross photosynthesis and respiration, while ammonium at the high concentration of $3.5 \mathrm{mM}$ inhibited both processes (Ludwig et al. 2006).

The fact that nitrate concentrations are often high in crystallizer ponds - often much higher than expected based on the passive concentration of seawater alone, and generally exceed the concentrations of ammonium, is still unexplained. In the evaporation ponds of the Santa Pola, Alicante salterns, turnover of nitrate $\left(\sim 100 \mathrm{~d}\right.$ turnover time at salinities below $\left.220 \mathrm{~g} \mathrm{l}^{-1}\right)$ was much slower than that of ammonium (2 to $14 \mathrm{~d}$ turnover time). On the other hand, rapid light-dependent uptake of nitrate was found in the crystallizer ponds (6 to $12 \mathrm{~d}$ turnover time at $370 \mathrm{~g} \mathrm{l}^{-1}$ salt). 
Table 3. Nutrient concentrations reported from saltern evaporation and crystallizer ponds. If necessary, values reported were converted to $\mu \mathrm{M}$

\begin{tabular}{|c|c|c|c|c|c|c|}
\hline Location & $\begin{array}{l}\text { Salinity } \\
\left(\mathrm{g} \mathrm{l}^{-1}\right)\end{array}$ & $\begin{array}{l}\text { Ammonium-N } \\
(\mu \mathrm{M})\end{array}$ & $\begin{array}{l}\text { Nitrate-N } \\
\quad(\mu \mathrm{M})\end{array}$ & $\begin{array}{l}\text { Phosphate } \\
\qquad(\mu \mathrm{M})\end{array}$ & $\begin{array}{c}\text { Comments } \\
\text { (concentrations } \\
\text { in } \mu \mathrm{M} \text { ) }\end{array}$ & Source \\
\hline \multicolumn{7}{|l|}{ Europe } \\
\hline Santa Pola, & 370 & 3.9 & 6.2 & & & Joint et al. (2002) \\
\hline \multirow{2}{*}{ Alicante, Spain } & 316 & $1-2$ & 6.2 & & & \\
\hline & $54-150$ & $1.5-2.4$ & $3-4$ & & & \\
\hline \multirow[t]{2}{*}{$\begin{array}{l}\text { Bras del Port, } \\
\text { Alicante, Spain }\end{array}$} & $\begin{array}{l}\text { Crystallizer ponds } \\
\quad(320-370)\end{array}$ & $150-230$ & $4-18$ & $5-7$ & Nitrite 8 & $\begin{array}{l}\text { Pedrós-Alió } \\
\text { et al. (2000) }\end{array}$ \\
\hline & $\begin{array}{l}\text { Evaporation ponds } \\
\qquad(40-250)\end{array}$ & $40-230$ & $0-4$ & $4-8$ & Nitrite 8 & \\
\hline \multirow[t]{2}{*}{$\begin{array}{l}\text { La Trinitat, Ebro } \\
\text { Delta, Spain }\end{array}$} & $\begin{array}{l}\text { Crystallizer ponds } \\
(300-370)\end{array}$ & $3-4$ & $0-38$ & $1-2$ & Nitrite 0 & $\begin{array}{l}\text { Pedrós-Alió } \\
\text { et al. (2000) }\end{array}$ \\
\hline & $\begin{array}{l}\text { Evaporation ponds } \\
\qquad(40-250)\end{array}$ & $3-13$ & $0-3$ & $2-3$ & & \\
\hline \multirow[t]{2}{*}{$\begin{array}{l}\text { Salin de Giraud, } \\
\text { France }\end{array}$} & All salnities?? & & $<2.0-25$ & $<0.01-0.02$ & & $\begin{array}{l}\text { Landry \& Jaccard } \\
\text { (1982) }\end{array}$ \\
\hline & All salinities & $\begin{array}{l}\text { Up to } 500 \text { near } \\
\text { decomposing } \\
\text { mats }\end{array}$ & $\begin{array}{c}\text { Up to } 25 \\
\text { in crystallizer } \\
\text { ponds }\end{array}$ & $<0.04$ & & $\begin{array}{l}\text { Britton \& Johnson } \\
\text { (1987) }\end{array}$ \\
\hline Burgas, Bulgaria & Crystallizer ponds & & & 8.6 & $\begin{array}{c}\text { Total N } \\
\text { (ammonium + } \\
\text { nitrate) } 2.2\end{array}$ & $\begin{array}{l}\text { Pavlova et al. } \\
\text { (1980) }\end{array}$ \\
\hline $\begin{array}{l}\text { Megalon Embolon } \\
\text { salt works, Greece }\end{array}$ & $65-144$ & $6-16 \mathrm{mg} \mathrm{l}^{-1}$ & $\begin{array}{c}0.9- \\
1.9 \mathrm{mg} \mathrm{l}^{-1}\end{array}$ & $\begin{array}{c}0.07- \\
0.21 \mathrm{mg} \mathrm{l}^{-1}\end{array}$ & & $\begin{array}{l}\text { Dolapsakis et al. } \\
\text { (2005) }\end{array}$ \\
\hline \multicolumn{7}{|l|}{ Australia } \\
\hline \multirow{2}{*}{$\begin{array}{l}\text { Dampier salterns, } \\
\text { W. Australia }\end{array}$} & Evaporation ponds & & & $0.05-0.13$ & & Sammy (1983) \\
\hline & Crystallizer ponds & & & $\begin{array}{l}\text { Below detection } \\
\text { limit }\end{array}$ & & \\
\hline $\begin{array}{l}\text { Cheetham salterns, } \\
\text { Queensland }\end{array}$ & Different salinities & & & $0.16-0.48$ & & $\begin{array}{l}\text { Coleman \& White } \\
\text { (1993) }\end{array}$ \\
\hline \multicolumn{7}{|l|}{ America } \\
\hline \multirow{2}{*}{$\begin{array}{l}\text { Exportadora de } \\
\text { Sal, Baja } \\
\text { California, } \\
\text { Mexico }\end{array}$} & $\begin{array}{l}\text { Evaporation ponds } \\
\text { all salinities }\end{array}$ & $<5$ & $<1$ & $<0.2$ & & Javor $(1983 a, b)$ \\
\hline & Crystallizer ponds & $5-10$ & $10-20$ & pl & $\begin{array}{l}\text { In bittern ponds } \\
\text { phosphate up to } 10 \text {, } \\
\text { nitrate up to } 30 \\
\text { ammonium up to } 50\end{array}$ & \\
\hline \multicolumn{2}{|c|}{$\begin{array}{l}\text { Western Salt, } \\
\text { Chula Vista, CA, USA salinities }\end{array}$} & $2-20$ & $2-36$ & $0-3.5$ & & Javor $(1983 a, b)$ \\
\hline $\begin{array}{l}\text { Cabo Rojo, } \\
\text { Puerto Rico }\end{array}$ & $\begin{array}{l}\text { Evaporation ponds, } \\
\text { wet season, } \\
40-150 ; \\
\text { dry season } \\
150-265\end{array}$ & $\begin{array}{l}>400 \text { (wet season) } \\
<8 \text { (dry season) }\end{array}$ & & $<0.2-3.5$ & & $\begin{array}{l}\text { Casillas-Martinez } \\
\text { et al. (2005) }\end{array}$ \\
\hline \multicolumn{7}{|l|}{ Worldwide } \\
\hline $\begin{array}{l}\text { Worldwide } \\
\text { average }\end{array}$ & Crystallizer ponds & 15 & 10 & 1 & & $\begin{array}{l}\text { Davis \& Giordano } \\
\text { (1996) }\end{array}$ \\
\hline \multirow[t]{2}{*}{$\begin{array}{l}\text { Worldwide } \\
\text { typical values }\end{array}$} & Gypsum ponds & $\begin{array}{l}0-7 \text { in oligotrophic } \\
\text { salterns, } 1-50 \text { in } \\
\text { eutrophic salterns }\end{array}$ & & $\begin{array}{l}<1 \text { in oligotrophic } \\
\text { salterns, } 1-10 \text { in } \\
\text { eutrophic salterns }\end{array}$ & & Javor (2002) \\
\hline & Crystallizer ponds & $\begin{array}{l}0-7 \text { in oligotrophic } \\
\text { salterns, } 5-50 \text { in } \\
\text { eutrophic salterns }\end{array}$ & $\begin{array}{c}\text { Typically } \\
\text { non- } \\
\text { detectable }\end{array}$ & $\begin{array}{c}0-2 \text { in oligotrophic } \\
\text { salterns, up to } 2-60 \\
\text { in eutrophic } \\
\text { salterns }\end{array}$ & & \\
\hline
\end{tabular}


Dunaliella salina can use both ammonium and nitrate as nitrogen source (Gibor 1956, Giordano \& Beardall 2006). An unexpected and still unexplained finding in these studies was that far more nitrate and ammonium were taken up than could have been predicted from the carbon fixation rate: instead of the classic C:N Redfield ratio of $16: 1$, values found were as low as 1.0 at $220 \mathrm{~g} \mathrm{l}^{-1}$ salt and even 0.8 at $370 \mathrm{~g} \mathrm{l}^{-1}$ salt (Joint et al. 2002). The source of the often high nitrate concentrations in the salterns, however, is far from clear: autotrophic nitrification, which in normal environments is responsible for the oxidation of ammonium through nitrite to nitrate, does not operate at salt concentrations above 100 to $150 \mathrm{~g} \mathrm{l}^{-1}$ (Oren 1999, 2001).

An essential nutrient generally neglected in studies of saltern ecosystems is iron. Laboratory experiments with Dunaliella salina have shown that exposure to increasing salt concentrations triggers the induction of a membranal transferrin-like protein that is most probably involved in the scavenging of iron. The possibility has therefore been raised that salt concentrations may affect $\mathrm{Fe}^{3+}$ solubility or interfere with the iron uptake machinery (Fisher et al. 1997, 1998). Studies on the presence and availability of iron and its impact on the dynamics of primary production and other microbial processes in the salterns are therefore long overdue.

Inorganic carbon can also become a limiting factor for photosynthesis, especially in microbial mats with dense cyanobacterial communities. Carbon limitation can often be recognized by the enrichment in ${ }^{13} \mathrm{C}$ in the organic matter formed, following depletion of ${ }^{12} \mathrm{C}$ that is preferentially used in photosynthesis. Thus, high $\%{ }^{13} \mathrm{C}$ values in specific lipids and other compounds extracted from the microbial mats in the La Trinitat and the Ebro Delta salterns in Spain were presented as evidence that the system was $\mathrm{CO}_{2}$-limited (Schouten et al. 2001). When carbon limitation becomes even more extreme, invasion of isotopically light $\mathrm{CO}_{2}$ from the atmosphere (the 'Baertschi effect') may, on the other hand, cause ${ }^{13} \mathrm{C}$ depletion rather than ${ }^{13} \mathrm{C}$ enrichment, as shown in the brines overlying the gypsum crusts of the Eilat, Israel salterns (Lazar \& Erez 1990, 1992).

\section{FINAL COMMENTS}

On a global scale, solar salterns are not a major ecosystem that contributes much to primary production. However, the highly diverse biological system of the salterns, with evaporation and crystallizer ponds of different salinities, and with often high densities of planktonic as well as benthic phototrophic microorganisms, makes salterns excellent model systems for the study of primary production under a variety of conditions. Moreover, their generally good accessibility and the relatively constant conditions maintained in each pond make the salterns a suitable environment for the study of fundamental questions about the activities of phototrophic microbial communities and the way these communities respond to their environment.

The potential that salterns thus offer to biologists has in many cases been extensively exploited. This is especially true for the benthic microbial mats that develop on the bottom of evaporation ponds of salterns worldwide. An in-depth understanding of the functioning of such mats has been obtained, including that on the tight coupling of primary production processes with other biogeochemical cycling processes operative in the system, often resulting in an efficient recycling of carbon through the mats (Canfield \& Des Marais 1993, Des Marais 1995). The layered microbial communities are often embedded within a crust of gypsum that stabilizes the spatial arrangement of the organisms, making manipulation relatively easy. Other aspects of the biology of the phototrophs in salterns are still relatively neglected. For example, only few studies have addressed the planktonic microorganisms in the lower and intermediate salinity evaporation ponds and their activities. A notable exception is the recent study by Estrada et al. (2004) that examined the diversity of planktonic photoautotrophic microorganisms along a salinity gradient by microscopy, flow cytometry, pigment analysis, and DNA-based methods. Another neglected aspect is the possible importance of organic osmotic solutes that have to be produced in large amounts and accumulated in the cells to provide osmotic balance according to the salinity of the brines (Oren 2000, 2006). To what extent the biosynthesis of compounds like glycerol (made by Dunaliella in the crystallizer ponds), and glycine betaine, glucosylglycerol and others (accumulated by halophilic Cyanobacteria) affects primary production processes and to what extent such compounds may later be key substrates for heterotrophic microorganisms present in the system is still incompletely known (Oren 1993, 1995). We are still far removed from an understanding of the true activities of Dunaliella salina in saltern crystallizer ponds, where this alga is always present in large numbers. On the other hand, attempts to estimate its photosynthetic activities invariably yielded low values. As discussed above, the problem may partly be due to methodological problems, as techniques routinely applied in freshwater and marine phytoplankton studies may not always be suitable for the study of microorganisms that live in saltsaturated brines.

To answer these fundamental questions in primary production research, salterns present us with a convenient experimental system, and the results obtained in such studies are important not only for our understanding of photosynthetic processes in hypersaline lakes, but also in the marine and freshwater environments. 
Acknowledgements. I thank the Israel Salt Company in Eilat, Israel for allowing access to the salterns, and for the use of their facilities during many years of study of the salt ponds. Different aspects of our past research in Eilat were financially supported by the Danish Basic Research Foundation (Grundforskningsfonden), the Danish Research Agency (Statens Naturvidenskablige Forskningsråd), the Israel Science Foundation, the State of Lower-Saxony and the Volkswagen Foundation, Hannover, Germany. My current research on Dunaliella in saltern crystallizer ponds is supported by the Israel Science Foundation (grant no. 617/07). I also thank the Batsheva de Rothschild Foundation, Bar Ilan University, the Moshe Shilo Center for Marine Biogeochemistry, and the Interuniversity Institute for Marine Sciences of Eilat for funding and logistic support. This review was presented as a keynote lecture at the Batsheva de Rothschild seminar on Gross and Net Primary Productivity within the framework of the 8th International Workshop of the Group for Aquatic Primary Productivity (GAP) held at the Interuniversity Institute for Marine Sciences in Eilat, Israel in April 2008.

\section{LITERATURE CITED}

Bonython CW (1966) Factors determining the rate of solar evaporation in the production of salt. In: Proc 2nd Symp on Salt. The Northern Ohio Geographical Society, Cleveland, OH, p 152-167

Britton RH, Johnson AR (1987) An ecological account of a Mediterranean salina: the Salin de Giraud, Camargue (S. France). Biol Conserv 42:185-230

Burke CM, Atkinson MJ (1988) Measurement of total alkalinity in hypersaline waters: values of $f_{\mathrm{H}}$. Mar Chem 25:49-55

Canfield DE, Des Marais DJ (1993) Biogeochemical cycles of carbon, sulfur, and free oxygen in a microbial mat. Geochim Cosmochim Acta 57:3971-3984

Canfield DE, Sørensen K, Oren A (2004) Biogeochemistry of a gypsum-encrusted microbial ecosystem. Geobiology 2: $133-150$

Casillas-Martinez L, Gonzalez ML, Fuentes-Figueroa Z, Castro CM and others (2005) Community structure, geochemical characteristics and mineralogy of a hypersaline microbial mat, Cabo Rojo, PR. Geomicrobiol J 22:269-281

Caumette P, Matheron R, Raymond N, Relexans JC (1994) Microbial mats in the hypersaline ponds of Mediterranean salterns (Salins-de-Giraud, France). FEMS Microbiol Ecol 13:273-286

Coleman MU, White MA (1993) The role of biological disturbances in the production of solar salt. 7 th Symp Salt 1: $623-631$

Cornée A (1982) Bactéries des saumures et des sédiments des marais salants de Salin-de-Giraud (Sud de la France). Geol Mediterr 9:369-389

Davis JS (1993) Biological management for problem solving and biological concepts for a new generation of solar saltworks. 7th Symp Salt 1:611-616

> Davis JS, Giordano M (1996) Biological and physical events involved in the origin, effects, and control of organic matter in solar saltworks. Int J Salt Lake Res 4:335-347

De Medeiros Rocha R, Camara MR (1993) Prediction, monitoring and management of detrimental algal blooms on solar salt production in northeast Brazil. 7th Symp Salt 1: $657-660$

> Decker KLM, Potter CS, Bebout BM, Des Marais DJ and others (2005) Mathematical simulation of the diel O, S, and C biogeochemistry of a hypersaline microbial mat. FEMS Microbiol Ecol 52:377-395
Des Marais DJ (1995) The biogeochemistry of hypersaline microbial mats. In: Jones JG (ed) Advances in microbial ecology, Vol 14. Plenum Press, New York, p 251-274

> Dolapsakis NP, Tafas T, Abatzopoulos TJ, Ziller S, EconomouAmilli A (2005) Abundance and growth response of microalgae at Megalon Embolon solar saltworks in northern Greece: an aquaculture prospect. J Appl Phycol 17: $39-49$

Elevi Bardavid R, Khristo P, Oren A (2008) Interrelationships between Dunaliella and halophilic prokaryotes in saltern crystallizer ponds. Extremophiles 12:5-15

Estrada M, Henriksen P, Gasol JM, Casamayor EO, PedrósAlió C (2004) Diversity of planktonic photoautotrophic microorganisms along a salinity gradient as depicted by microscopy, flow cytometry, pigment analysis and DNAbased methods. FEMS Microbiol Ecol 49:281-293

Fisher M, Gokhman I, Pick U, Zamir A (1997) A structurally novel transferrin-like protein accumulates in the plasma membrane of the unicellular green alga Dunaliella salina grown in high salinities. J Biol Chem 272:1565-1570

- Fisher M, Zamir A, Pick U (1998) Iron uptake by the halotolerant alga Dunaliella grown in high salinities. J Biol Chem 273:17553-17558

Fourçans A, Garcia de Oteyza T, Wieland A, Solé A and others (2004) Characterization of functional bacterial groups in a hypersaline microbial mat community (Salins-deGiraud, Camargue, France). FEMS Microbiol Ecol 51: $55-70$

Garcia-Pichel F, Nübel U, Muyzer G (1998) The phylogeny of unicellular, extremely halotolerant Cyanobacteria. Arch Microbiol 169:469-482

Gibor A (1956) The culture of brine algae. Biol Bull 111: 223-229

Giordano M, Beardall J (2006) Impact of environmental conditions on photosynthesis, growth and carbon allocation strategies of hypersaline species of Dunaliella. In: Lekkas TD, Korovessis NA (eds) Proc 1st Int Conf on the Ecological Importance of Solar Saltworks (CEISSA 06), Santorini Island, Greece, 20-22 October 2006, p 65-71

Goldman JC, Dennett MR (1985) Susceptibility of some marine phytoplankton species to cell breakage during filtration and post-filtration rinsing. J Exp Mar Biol Ecol 86: $47-58$

Gunde-Cimerman N, Oren A, Plemenita? A (2005) Mikrosafari-Čudoviti svet mikroorganizmov solin. The beautiful world of microorganisms in the salterns. Bilingual Slovenian/English publication. Državna Založba Slovenije, Ljubljana

Ionescu D, Lipski A, Altendorf K, Oren A (2007) Characterization of the endoevaporitic microbial communities in a hypersaline gypsum crust by fatty acid analysis. Hydrobiologia 576:15-26

Javor BJ (1983a) Planktonic standing crop and nutrients in a saltern ecosystem. Limnol Oceanogr 28:153-159

Javor BJ (1983b) Nutrients and ecology of the Western Salt and Exportadora de Sal saltern brines. 6th Int Symp on Salt 1:195-205

Javor B (1989) Hypersaline environments. Microbiology and biogeochemistry. Springer-Verlag, Berlin

Javor BJ (2002) Industrial microbiology of solar salt production. J Ind Microbiol Biotechnol 28:42-47

Joint I, Henriksen P, Garde K, Riemann B (2002) Primary production, nutrient assimilation and microzooplankton grazing along a hypersaline gradient. FEMS Microbiol Ecol 39: $245-257$

Labbé A (1921) Sur les modifications adaptives de Dunaliella salina Dunal. C R Acad Sci 172:1074-1076 
Landry JC, Jaccard J (1982) Chimie des eaux libres dans le marais salant de Salin-de-Giraud (Sud de la France). Géol Mediterr 9:329-348

Lazar B, Erez J (1990) Extreme ${ }^{13} \mathrm{C}$ depletions in seawaterderived brines and their implications for the past geochemical carbon cycle. Geology 18:1191-1194

Lazar B, Erez J (1992) Carbon geochemistry of marinederived brines: I. ${ }^{13} \mathrm{C}$ depletions due to intense photosynthesis. Geochim Cosmochim Acta 56:335-354

Litchfield CD (1991) Red - the magic color for solar salt production. In: Hocquet J-C, Palme R (eds) Das Salz in der Rechts- und Handelsgeschichte. Berenkamp, Schwaz, p 403-412

Ludwig R, Pringault $\mathrm{O}$, de Wit R, de Beer D, Jonkers HM (2006) Limitation of oxygenic photosynthesis and oxygen consumption by phosphate and organic nitrogen in a hypersaline microbial mat: a microsensor study. FEMS Microbiol Ecol 57:9-17

Margheri MC, Tredici MR, Barsanti L, Balloni W (1987) The photosynthetic community of the Trapani saline lagoons: an alternative option for the exploitation of an extreme environment. Ann Microbiol 37:203-217

> Nübel U, Garcia-Pichel F, Clavero E, Muyzer G (2000) Matching molecular diversity and ecophysiology of benthic Cyanobacteria and diatoms in communities along a salinity gradient. Environ Microbiol 2:217-226

Oren A (1993) Availability, uptake, and turnover of glycerol in hypersaline environments. FEMS Microbiol Ecol 12:15-23

> Oren A (1995) The role of glycerol in the nutrition of halophilic archaeal communities: a study of respiratory electron transport. FEMS Microbiol Ecol 16:281-290

> Oren A (1997) Mycosporine-like amino acids as osmotic solutes in a community of halophilic Cyanobacteria. Geomicrobiol J 14:231-240

Oren A (1999) Bioenergetic aspects of halophilism. Microbiol Mol Biol Rev 63:334-348

Oren A (2000) Salts and brines. In: Whitton BA, Potts M (eds) Ecology of Cyanobacteria: their diversity in time and space. Kluwer Academic Publishers, Dordrecht, p 281-306

Oren A (2001) The bioenergetic basis for the decrease in metabolic diversity in increasing salt concentrations: implications for the functioning of salt lake ecosystems. Hydrobiologia 466:61-72

Oren A (2005a) Microscopic examination of microbial communities along a salinity gradient in saltern evaporation ponds: a 'halophilic safari'. In: Gunde-Cimerman N, Oren A, Plemenitaš A (eds) Adaptation to life at high salt concentrations in Archaea, Bacteria, and Eukarya. Springer, Dordrecht, p 41-57

Oren A (2005b) A hundred years of Dunaliella research: 1905-2005. Saline Systems 1:2

Oren A (2006) Life at high salt concentrations. In: Dworkin M, Falkow S, Rosenberg E, Schleifer K-H, Stackebrandt E (eds) The prokaryotes. A handbook on the biology of bacteria: ecophysiology and biochemistry, Vol 2. Springer, New York, p 263-282

> Oren A, Dubinsky Z (1994) On the red coloration of saltern crystallizer ponds. II. Additional evidence for the contribution of halobacterial pigments. Int J Salt Lake Res 3:9-13

Oren A, Stambler N, Dubinsky Z (1992) On the red coloration of saltern crystallizer ponds. Int J Salt Lake Res 1:77-89

> Oren A, Kühl M, Karsten U (1995) An endoevaporitic microbial mat within a gypsum crust: zonation of phototrophs, photopigments, and light penetration. Mar Ecol Prog Ser 128:151-159
Oren A, Sørensen KB, Canfield DE, Teske AP, Ionescu D, Lipski A, Altendorf K (2009) Microbial communities and processes within a hypersaline gypsum crust in a saltern evaporation pond (Eilat, Israel). Hydrobiologia 626:15-26

Ortí Cabo F, Pueyo Mur JJ, Truc G (1984) Las salinas marítimas de Santa Pola (Alicante, España). Breve introducción al estudio de un medio natural controlado de sedimentación evaporítica somera. Rev Invest Geol 38/39: 9-29

Pavlova P, Markova K, Tanev S, Davis JS (1998) Observations on a solar saltworks near Burgas, Bulgaria. Int J Salt Lake Res 7:357-368

Pedrós-Alió C, Calderón-Paz JI, MacLean MH, Medina G, Marrasé C, Gasol JM, Guixa-Boixereu N (2000) The microbial food web along salinity gradients. FEMS Microbiol Ecol 32:143-155

Rahaman AA, Ambikadevi M, Sosamma-Esso (1993) Biological management of Indian solar saltworks. 7th Symp on Salt 1:633-643

> Rodriguez-Valera F, Ventosa A, Juez G, Imhoff JF (1985) Variation of environmental features and microbial populations with salt concentration in a multi-pond saltern. Microb Ecol 11:107-115

> Roux JM (1996) Production of polysaccharide slime by microbial mats in the hypersaline environment of a Western Australian solar saltfield. Int J Salt Lake Res 5:103-130

Sammy N (1983) Biological systems in northwestern Australian solar salt fields. 6th Int Symp on Salt 1:207-215

Schneider J (1995) Eindunstung von Meerwasser und Salzbildung in Salinen. Kali Steinsalz 11:325-330

Schouten S, Hartgers WA, Lòpez JF, Grimalt JO, Sinninghe Damsté JS (2001) A molecular isotopic study of ${ }^{13} \mathrm{C}$ enriched organic matter in evaporitic deposits: recognition of $\mathrm{CO}_{2}$-limited ecosystems. Org Geochem 32:277-286

Sherwood JR, Stagnitti F, Kokkinn MJ, Williams WD (1991) Dissolved oxygen concentrations in hypersaline waters. Limnol Oceanogr 36:235-250

> Sherwood JR, Stagnitti F, Kokkinn MJ, Williams WD (1992) A standard table for predicting equilibrium dissolved oxygen concentrations in salt lakes dominated by sodium chloride. Int J Salt Lake Res 1:1-6

Solórzano L (1969) Determination of ammonia in natural waters by the phenol hypochlorite method. Limnol Oceanogr 14:799-801

Sørensen KB, Canfield DE, Oren A (2004) Salt responses of benthic microbial communities in a solar saltern (Eilat, Israel). Appl Environ Microbiol 70:1608-1616

Sørensen KB, Canfield DE, Teske AP, Oren A (2005) Community composition of a hypersaline endoevaporitic microbial mat. Appl Environ Microbiol 71:7352-7365

Thomas JC (1984) Formations benthiques à Cyanobactéries des salins de Santa Pola (Espagne): composition spécifique, morphologie et caractéristiques biologiques des principaux peuplements. Rev Invest Geol 38/39:139-158

Wieland A, Kühl M (2006) Regulation of photosynthesis and oxygen consumption in a hypersaline cyanobacterial mat (Camargue, France) by irradiance, temperature and salinity. FEMS Microbiol Ecol 55:195-210

Wieland A, Zopfi J, Benthien M, Kühl M (2005) Biogeochemistry of an iron-rich hypersaline microbial mat (Camargue, France). Microb Ecol 49:34-49

Wright RC (1983) A modified field version of the Winkler determination of dissolved oxygen for testing remote sources of water. New Phytol 95:37-40

Submitted: March 30, 2008; Accepted: February 3, 2009

Proofs received from author(s): June 21, 2009 